\title{
A Cross-Sectional Study on Knowledge, Attitude and Practice To- wards Covid-19 Among The Parents Of Covid Positive Children Ad- mitted At tertiary care hospital
}

\author{
Adarsh $E^{1}$, Nagajyothi $S^{2}$, Sangethya $A^{3}$
}

1. Professor and HOD, Department Of Pediatrics,RajaRajeswari Medical College \& Hospital, 202, Mysore Rd, Kengeri Satellite Town, Kambipura, Karnataka

2.Assistant Professor, Department Of Pediatric, Department Of Pediatrics,RajaRajeswari Medical College \& Hospital, 202, Mysore Rd, Kengeri Satellite Town, Kambipura, Karnataka

3. Post graduate Student, Department Of Pediatric, Department Of Pediatrics,RajaRajeswari Medical College \& Hospital, 202, Mysore Rd, Kengeri Satellite Town, Kambipura, Karnataka

DOI:10.47799/pimr.0901.16

- Corresponding author: Dr. Sangethya A, Department Of Pediatric, Department Of Pediatrics, RajaRajeswari Medical College \& Hospital, 202, Mysore Rd, Kengeri Satellite Town, Kambipura, Karnataka

Received: 13/3/2021

Peer review:01/4/2021

Accepted: 28/4/2021

\section{ABSTRACT}

Background : SARS-CoV-2 has caused a global pandemic. India being a populated country and much about the virus was remained unknown, its way more difficult to control with inadequate knowledge among general public. We aimed to identify Knowledge, Attitude and Practice (KAP) studies among Parents of covid 19 infected children as it can identify crucial knowledge gaps and gauge psychological impact.

Material : A cross-sectional, questionnaire-based study was conducted among parents of covid 19 infected children. The questionnaire identified participants' demographics and the current KAP related to COVID-19.

Results : Of 224 total participants, $27.7 \%$ belonged to age group $30-40$ years. Female constituted $50.4 \% .73 .7 \%$ of participants had adequate knowledge. $57.1 \%$ had positive attitude towards COVID. $46.9 \%$ participants practiced preventive strategies. KAP compared with age group showed there is a statistically significant difference in Knowledge in the Age-Groups, but there was no statistical significance difference in Attitude and Practice in the Age-groups.

Conclusion: $73.7 \%$ parents had good knowledge about covid 19 , inadequate attitude and insensitive practice towards covid 19 can be a real threat. For effective containment of the pandemic and the new wave of corona virus existing barriers need to be addressed by promoting behavioral changes.
Keywords: Knowledge, Attitude, Practice, COVID-19, Parents, India

\section{Introduction}

The coronavirus disease 2019 (COVID-19) as known was emerged in Wuhan, China in December 2019. (1) Since then, it has spread to 215 countries and has been declared a global pandemic by the World Health Organization (WHO) ${ }^{(2)}$.It is highly contagious with a certain mortality rate, and it was classified as a class B infectious disease and managed as a class A infectious disease in China in January $2020^{(3)}$. World's second most populous country and the largest in south Asia, with a population of nearly 1.4 billion, therefore, it is at risk of having the largest share of these potential infections and deaths. (4) Lockdown measures were perceived as necessary to curb the spread of the virus as rapid human-to-human transmission occurred. (5) It was observed that people were crowding in public transport to travel back to their hometowns, potentially increasing the risk of infection to other parts of the country. Seeing the present situation it raises questions regarding the level of understanding and attitudes toward COVID-19 among people. This survey can help us give a picture of awareness status of COVID-19 prevention practices and help in focusing on societal readiness to comply with pandemic control measures. 


\section{Adarsh et al}

\section{Materials and Method}

\section{Study Design and Population}

This is a institution based cross-sectional, observational study carried out on patients Caregiver admitted at Rajarajeswari medical college and hospital during 3 month period from July 15th 2020 to October 15th 2020 after ethical committee approval.

\section{Study Design and Population}

Questionnaire were prepared after a comprehensive literature search and based on the recent available information from the World Health Organization and Centre for Disease Control and Prevention. The questions were framed related to covid 19 in a simple and understandable language.

The questionnaire included two sections: 1. Demographics 2.Knowledge, Attitudes and Practices question (KAP).Demographic variables includes age, gender, occupation and socio economic status. The first part is investigation of knowledge, consisting of questions about COVID-19 and its clinical presentations, transmission routes. Attitudes towards COVID-19 were appraised which includes level of agreement on the COVID-19 control implementations and the confidence perception for winning the war against this corona virus. There were Questions that investigated their actions towards going to a crowded place, wearing masks when going out in recent days, maintaining social distance between others and if they agree for home isolation for mild symptomatic cases and isolating themselves after their exposure to COVID-19. Finally, one last question was added to inquire about the source of COVID-19 information. These questions were answered on Yes or No or I don't know option. Points were assigned for all responses, for each correct response one point, no points for an incorrect/unknown answer. The total score ranged from 0 to 30 , higher the score suggesting better COVID-19 awareness.

\section{RESULTS}

\section{Demographic characteristics}

Frequency and percentage of all demographic characteristics like gender, age, and education are represented in [Table 1]. Out of the 224 participants, $49.6 \%$ were males while the rest were female $(50.4 \%)$; the majority of them were $30-40$ years old $27.7 \%$ of the respondents educational status is SSLC.

\begin{tabular}{|l|c|c|}
\hline \multicolumn{1}{|c|}{ Qualification } & $\begin{array}{c}\text { No. of } \\
\text { Respondents }\end{array}$ & Percent \\
\hline Uneducated & 8 & 3.6 \\
\hline Primary School & 7 & 3.1 \\
\hline Middle School & 13 & 5.8 \\
\hline
\end{tabular}

www. pimr.org.in

\begin{tabular}{|l|c|c|}
\hline High School & 21 & 9.4 \\
\hline SSLC & 62 & 27.7 \\
\hline PUC & 34 & 15.2 \\
\hline Graduate & 44 & 19.6 \\
\hline Postgraduate & 14 & 6.3 \\
\hline Professional & 21 & 9.4 \\
\hline & $\begin{array}{c}\text { Female } \\
{[\mathbf{n}(\%)]}\end{array}$ & $\begin{array}{c}\text { Male } \\
{[\mathbf{n}(\%)]}\end{array}$ \\
\hline $20-30 \quad$ Group & $45(39.8 \%)$ & $6(5.4 \%)$ \\
\hline $30-40$ & $57(50.4 \%)$ & $64(57.7 \%)$ \\
\hline $40-50$ & $10(8.8 \%)$ & $38(34.2 \%)$ \\
\hline $50-60$ & $1(0.9 \%)$ & $3(2.7 \%)$ \\
\hline & No. of & Percent \\
\hline Female & 113 & 50.4 \\
\hline Male & 111 & 49.6 \\
\hline Total & 224 & 100.0 \\
\hline
\end{tabular}

Table 1: Socio demographic characteristics of participants

\section{KNOWLEDGE}

The majority of the participants $(73.7 \%)$ had good knowledge about COVID-19. 74.1\% of the participants awared that early symptomatic and supportive treatment can help them recover from infection. Majority of the parents had correct knowledge about the transmission routes of the virus; however, only half of the total participants had knowledge that covid can be transmitted through fomites. Furthermore, $95.1 \%$ of participants realized that people who have come in contact with someone infected with the COVID-19 virus should be isolated for 14 day. 


\begin{tabular}{|c|c|c|c|c|c|c|c|}
\hline \multirow{2}{*}{ SI.No. } & \multirow{2}{*}{ Knowledge Section } & \multicolumn{2}{|c|}{ Yes } & \multicolumn{2}{|c|}{ No } & \multicolumn{2}{|c|}{ Don't Know } \\
\hline & & $\mathbf{n}$ & $\%$ & $\mathbf{N}$ & $\%$ & $\mathbf{n}$ & $\%$ \\
\hline K1 & Can COVID-19 spreads through droplet infection? & 199 & 88.8 & 13 & 5.8 & 12 & 5.4 \\
\hline $\mathrm{K} 2$ & Clinical symptoms of COVID-19 are fever, cough, myalgia, shortness of breath? & 206 & 92.0 & 13 & 5.8 & 5 & 2.2 \\
\hline K3 & Can COVID-19 can be transmitted through fomites? & 119 & 53.1 & 34 & 15.2 & 71 & 31.7 \\
\hline K4 & $\begin{array}{l}\text { A person can contact COVID-19 even when fever is not present in positive } \\
\text { patients? }\end{array}$ & 170 & 75.9 & 36 & 16.1 & 18 & 8.0 \\
\hline K5 & Symptomatic and supportive treatment is the mainstay in COVID-19 patients? & 166 & 74.1 & 22 & 9.8 & 36 & 16.1 \\
\hline K6 & COVID-19 can be contracted through handshake with COVID-19 positive patients? & 189 & 84.4 & 31 & 13.8 & 4 & 1.8 \\
\hline K7 & COVID-19 positive patients should be isolated for 14 days? & 213 & 95.1 & 9 & 4.0 & 2 & 0.9 \\
\hline K8 & The disease is severe among elderly persons with chronic diseases? & 199 & 88.8 & 5 & 2.2 & 20 & 8.9 \\
\hline K9 & Contact with COVID-19 infected animals can transmit the disease to humans? & 37 & 16.5 & 75 & 33.5 & 112 & 50.0 \\
\hline K10 & COVID-19 causes severe disease in children? & 88 & 39.3 & 104 & 46.4 & 32 & 14.3 \\
\hline K11 & COVID-19 positive patients with mild symptoms can be home quarantined? & 170 & 75.9 & 32 & 14.3 & 22 & 9.8 \\
\hline $\mathrm{K} 12$ & Isolation of COVID-19 positive patients is an effective means of controlling disease transmission? & 161 & 71.9 & 61 & 27.2 & 2 & 0.9 \\
\hline K13 & Vaccine is effective means to control spread of disease? & 119 & 53.1 & 25 & 11.2 & 80 & 35.7 \\
\hline K14 & Antibiotics are effective treatment in COVID-19? & 112 & 50.0 & 6 & 2.7 & 106 & 47.3 \\
\hline
\end{tabular}

Table 2: Knowledge of parents about COVID-19.

\section{ATTITUDE}

Table 3 shows that the $(57.1 \%)$ had a good attitude towards Covid-19. 76.8\% of people agreed that avoiding crowded places can prevent infection.65.2\% believed that covid 19 can be successfully controlled.66.1\% parents were aware that avoiding playing outside with other children can prevent covid 19.

\begin{tabular}{|c|l|c|c|c|c|c|c|}
\hline \multirow{2}{*}{ SI.No. } & \multicolumn{1}{|c|}{ Attitude Section } & \multicolumn{2}{c|}{ Agree } & \multicolumn{2}{c|}{ Disagree } & \multicolumn{2}{c|}{ Neutral } \\
\cline { 3 - 8 } & & $\mathbf{n}$ & $\%$ & $\mathbf{N}$ & $\%$ & $\mathbf{n}$ & $\%$ \\
\hline A1 & To prevent infection will you avoid going to crowded places? & 172 & 76.8 & 52 & 23.2 & 0 & 0.0 \\
\hline A2 & Do you agree that all COVID-19 positive should be admitted to hospital? & 100 & 44.6 & 120 & 53.6 & 4 & 1.8 \\
\hline A3 & Will COVID-19 it be successfully controlled? & 146 & 65.2 & 59 & 26.3 & 19 & 8.5 \\
\hline A4 & Children should exercise regularly to boost immunity and prevent COVID-19? & 152 & 67.9 & 68 & 30.4 & 4 & 1.8 \\
\hline A5 & Children should not be allowed to play outside to prevent COVID-19? & 148 & 66.1 & 71 & 31.7 & 5 & 2.2 \\
\hline A6 & Do you think India can win battle against CovID-19 infection? & 127 & 56.7 & 97 & 43.3 & 0 & 0.0 \\
\hline
\end{tabular}

Table 3: Attitude of parents regarding COVID-19.

\section{PRACTICE}

Table 4 presents prevention practices and behavioural practices done by the participants were about $46.9 \%$. $65.2 \%$ of participants follow hand washing as they believe it can prevent covid 19 and they maintain social distance in public place during the outbreak. Though people were aware that travelling can spread covid $46 \%$ of parents took children out and $49.6 \%$ used public transport for travelling. 
Adarsh et al

www. pimr.org.in

\begin{tabular}{|c|l|c|c|c|c|c|c|}
\hline \multirow{2}{*}{ SI.No. } & \multicolumn{1}{|c|}{ Practice Section } & \multicolumn{2}{c|}{ Yes } & \multicolumn{2}{c|}{ No } & \multicolumn{2}{c|}{ Don't Know } \\
\cline { 3 - 7 } & & $\mathbf{n}$ & $\%$ & $\mathbf{N}$ & $\%$ & $\mathbf{n}$ & $\%$ \\
\hline P1 & Does your children wear mask while going out? & 149 & 66.5 & 75 & 33.5 & 0 & 0.0 \\
\hline P2 & Do you prefer public transport for your child? & 111 & 49.6 & 106 & 47.3 & 7 & 3.1 \\
\hline P3 & Do you maintain social distance when you are in public places? & 146 & 65.2 & 78 & 34.8 & 0 & 0.0 \\
\hline P4 & $\begin{array}{l}\text { Frequent hand washing with soap and water or hand sanitizer will reduce chance } \\
\text { of COVID-19 infection? }\end{array}$ & 146 & 65.2 & 78 & 34.8 & 0 & 0.0 \\
\hline P5 & Do you allow your children to play with other children? & 84 & 37.5 & 140 & 62.5 & 0 & 0.0 \\
\hline P6 & Have you taken your child out recently? & 103 & 46.0 & 121 & 54.0 & 0 & 0.0 \\
\hline P7 & One should avoid touching nose, mouth, eyes with unwashed hands? & 128 & 57.1 & 89 & 39.7 & 7 & 3.1 \\
\hline P8 & Children consume healthy food and drink clean water to boost immunity? & 139 & 62.1 & 85 & 37.9 & 0 & 0.0 \\
\hline P9 & If you come in contact with covID-19 positive persons will be isolate yourself for 14 days? & 200 & 89.3 & 16 & 7.1 & 8 & 3.6 \\
\hline
\end{tabular}

Table 4: Practice of Parents regarding COVID-19.

\section{ANALYSIS OF KAP SCORES WITH RESPECT TO AGE}

\begin{tabular}{|c|c|c|c|c|c|c|c|c|c|c|c|}
\hline KAP & $\begin{array}{l}\text { Age } \\
\text { Group }\end{array}$ & Min & Max & Mean & SD & Median & IQR & $\begin{array}{l}\text { Mean } \\
\text { Rank }\end{array}$ & $\begin{array}{l}\text { Sum of } \\
\text { Ranks }\end{array}$ & $\begin{array}{c}\text { Mann- } \\
\text { Whitney U }\end{array}$ & p-value \\
\hline \multirow{2}{*}{ Knowledge } & $=34$ & 0 & 13 & 9.62 & 2.64 & 10 & 2 & 120.81 & 14135 & \multirow{2}{*}{5287} & \multirow{2}{*}{0.042} \\
\hline & $>34$ & 3 & 13 & 9.25 & 2.28 & 9 & 3 & 103.41 & 11065 & & \\
\hline \multirow{2}{*}{ Attitude } & $=34$ & 0 & 6 & 3.64 & 1.42 & 4 & 2 & 110.65 & 12945.5 & \multirow{2}{*}{6042.5} & \multirow{2}{*}{0.645} \\
\hline & $>34$ & 0 & 6 & 3.78 & 1.23 & 4 & 2 & 114.53 & 12254.5 & & \\
\hline \multirow{2}{*}{ Practice } & $=34$ & 0 & 8 & 5.19 & 1.73 & 5 & 3 & 108.07 & 12644.5 & \multirow{2}{*}{5741.5} & \multirow{2}{*}{0.276} \\
\hline & $>34$ & 1 & 9 & 5.43 & 1.53 & 6 & 1 & 117.34 & 12555.5 & & \\
\hline
\end{tabular}

\section{Interpretation:}

Knowledge:

Median=10 with $I Q R=2$ in $=34$ years age group and Median=9 with IQR=3 in $>34$ years age group; Mann-Whitney $\mathrm{U}=5287$ with $\mathrm{p}$-value $=0.042<0.05$,

Therefore there is a statistical significance difference in knowledge in $=34$ and $>34$ years age-group. And Mean Rank of $=34$ years age-group is 120.81 highest mean rank, has good knowledge.

Attitude:

Median=4 with IQR=2 in both the age groups i.e. $=34$ \& >34 years; Mann-Whitney $U=6142.5$ with $p$-value $=0.645$ > 0.05 ,

Therefore there is no statistically significance difference in Attitude in $=34 \&>34$ years age-group. And Mean Rank of $>34$ years age-group is 114.53 highest mean rank, has good attitude.
Practice:

Median=5 with $I Q R=3$ in $=34$ years age group and Median=6 with IQR=1 in $>34$ years age group; Mann-Whitney $\mathrm{U}=5741.5$ with $\mathrm{p}$-value $=0.276>0.05$

Therefore there is no statistically significance difference in Attitude in = 34 \& >34 years age-group. And Mean Rank of = 34 years age-group is 122.41 highest mean rank, has good practice.

Therefore from the above table we can conclude that there is a statistically significant difference in Knowledge in the Age-Groups, and there was no statistical significance difference in Attitude and Practice in the Age-groups.

However highest Mean Rank is observed in Knowledge in = 34 years age-group and highest Mean Rank is observed in Attitude and Practice in $>34$ years age-group. 


\section{Adarsh et a}

\section{DISCUSSION}

The survey was an initiative to understand KAP towards COVID-19among the parents whose children were admitted due to covid 19 .The predominant age group 30-40 years(54.05\%), among them $27.7 \%$ mostly educated up to SSLC, source of information being television for $70.5 \%$ although these platforms provide an easy and accessible ways of getting information, they can also be a source of misinformation and physician $12.5 \%$.. The response rate was $73.7 \%$ for knowledge score, reflecting incomplete awareness regarding COVID-19. It could be attributed to the spread of myths and misinformation driven by fear, blame and stigma and even due to poor educational status. This throws light that there is a need to strengthen existing awareness initiatives.

Despite inadequate knowledge, majority (89.3\% )of participants practiced and believed that isolating themselves is required if they come in contact covid. $(6,7)$.Implementation of avoiding overcrowding, frequent hand washing and maintenance of social distancing something very difficult but almost $65.2 \%$ extended their support and followed restrictive policies thus reflecting trust in scientific leadership.(8)

Despite the lockdown, around $46 \%$ of participants got their children's out of their houses for either playing, travelled out of station with all preventive measures. This risky behavior is detrimental as it can effectuate into silent community transmission.(9) It warrants educational and promotional road map to augment cognizance and compliance of the population during pandemic crisis.

\section{CONCLUSION}

This study provides a comprehensive analysis of the COVID-19 KAP among parents. The findings suggested that although they have acceptable level of knowledge on COVID19 , awareness and preventive measures were quite alarming and require urgent consideration. Considering the possibility that as during covid 19 all the parents were at home and mothers had to take care of the children and household work the awareness of covid 19 was poor. Our study also showed that parents allowed their children to go out and play. Considering the possibility of prolonged pandemic situation and possible second wave, consistent reinforcement of preventive guidelines from the health authorities is very essential to maintain strict adherence by the general public which could help in preventing COVID 19.

\section{REFERENCES}

1. Eurosurveillance Editorial T. Note from the editors: World Health Organization Declares novel coronavirus (2019nCoV) sixth public health emergency of international concern.Euro surveillance : bulletin Europeen sur les maladies transmissibles $=$ European communicable disease bulletin.2020;25(5). Epub 2020/02/06. www. pimr.org.in

2. World Health Organization. Coronavirus disease (COVID 19). Situation Report - 118, 17 May 2020. Available from: https://www.who.int/emergencies/diseases/novelcoronavirus-2019/situation-reports. [Last accessed on 2020 May 18].

3. China National Health Commission. Homepage. [Online] Available from: http://www.nhc.gov.cn/jkj/s7916/202001/ 44a3b8245e8049d2837a 4f27529cd386.shtml. [Accessed on March 20th 2020].

4. Government of india Ministry of Information and Broadcasting. India's response to COVID outbreak.https:/ /pib.gov.in/PressReleasePage.aspx?PRID=1608727.Date accessed: March 28, 2020

5. Golechha M. COVID-19, India, lockdown and psychosocial challenges: What next? International Journal of Social Psychiatry. 2020;66(8):830-832. doi:10.1177/ 002076402093592

6. Maheshwari S, Gupta PK, Sinha R, Rawat P. Knowledge, attitude, and practice towards coronavirus disease 2019 (COVID-19) among medical students: A cross-sectional study. J Acute Dis 2020;9:100-4

7. Abdelhafiz, A. S., Mohammed, Z., Ibrahim, M. E., Ziady, H. H., Alorabi, M., Ayyad, M., \& Sultan, E. A. (2020) Knowledge, Perceptions, and Attitude of Egyptians Towards the Novel Coronavirus Disease (COVID-19). Journal of community health, 45(5), 881-890. https:// doi.org/10.1007/s10900-020-00827-7

8. Rajon Banik, Mahmudur Rahman, Dr. Md. Tajuddin Sikder et al. Investigating knowledge, attitudes, and practices related to COVID-19 outbreak among Bangladeshi young adults: A web-based cross-sectional analysis, 23 July 2020, PREPRINT (Version 2) available at Research Square [https:/ /doi.org/10.21203/rs.3.rs-37946/v2].

9. Frieden TR, Lee CT. Identifying and interrupting superspreading events-implications for control of severe acute respiratory syndrome coronavirus 2. Emerg Infect Dis 2020;26:1059-66

How to cite this article : Adarsh E, Nagajyothi S, Sangethya A. A Cross-Sectional Study on Knowledge, Attitude and Practice Towards Covid-19 Among The Parents Of Covid Positive Children Admitted At tertiary care hospital. Perspectives in Medical Research 2021; 9 (1):79-83 DOI:10.47799/pimr.0901.16

Sources of Support: Nil, Conflict of interest: None declared 